\title{
Participation of the Young Generation in Family-OWned Businesses
}

\author{
Zuzana Horčičková \\ Technical University of Liberec, Faculty of Economics, \\ Department of Business Administration and Management, \\ Studentská 1402/2, 46117 Liberec, Czech Republic \\ e-mail: zuzana.horcickova@tul.cz
}

\begin{abstract}
The article is based on research which was focused on students in their last year of studies at secondary vocational schools, high schools, vocational colleges, and, subsequently, at public universities in the Liberec Region. The author's doctoral thesis deals with the complex decision-making process of young people leading to taking over the family business [1]. Based on the results of the analysis, a basic scheme of participation of young people in family business in the Liberec Region was created. The factors that influence the individual stages of the decision-making process are identified and summarized, taking into account the type of municipality in which the family business is run. It also considers the type of family business, i.e. whether it is a Family Business Corporation or Family Business of Natural Persons.
\end{abstract}

\section{Keywords}

Family business type; Student; Decision process; Succession; Municipality; Liberec Region.

\section{Introduction}

Family-owned businesses are considered a significant part of every country's economy. They represent tradition and stability [2]. Passing this type of business down to the next generation is one of its greatest and most fundamental traits, as well as its greatest potential pitfall. Nowadays in the Czech Republic, the issue of succession is at the forefront of many people's minds, as, in many cases, this is the first intergenerational transfer (the first generation to pass on the family business to the next). Studies focusing on succession in family businesses have revealed a prevalent unwillingness of the young generation to take over their family businesses. This unwillingness may bring about disappearance of the family element of entrepreneurship and the advantages linked to it, such as acquiring tacit knowledge which will not be passed on by the existing generation to the next, thus preventing it from being further enhanced.

Examining the aspects of business entities (regardless of their family aspect) requires considering the place of business of the entrepreneur. The doctoral thesis is focused on the differentiation of businesses from this perspective, i.e. on whether an entrepreneur is engaged in business in rural or urban areas. Based on an evaluation of the current state of research in respect of family businesses, including the issue of succession, the principal objective of the doctoral thesis was determined, i.e. developing a scheme of the participation of young people in family businesses within an area, focusing on their willingness to take over the business.

The definition of family business and family business types is based on the definition of AMSP ČR [3] and Rydvalová et al. [4] in this research. These approaches have been identified on the basis researches and discussions in this field in the Czech Republic. Definitions of family businesses were simplified by the author in the survey to make them understandable to respondents. 
The key characteristic is the involvement of at least two family members in the business. In terms of this research, the following are considered to be family businesses:

1) Family Business Corporation (FBC): a business corporation in which the family holds at least a 50\% ownership interest and in which 2 family members are involved, whether through work or ownership.

2) Family Business of Natural Persons (FB NP) where are included:

a) Family Enterprise: A family member does business as a natural person under the Trade Licensing Act or other laws, and at least 1 other family member helps without any contract/agreement.

b) Family Agglomeration:

i) A family member does business as a natural person under the Trade Licensing Act or other laws, and at least 1 other family member helps pursuant to a contract/agreement;

ii) Multiple family members do business as natural persons under the Trade Licensing Act or other laws and they cooperate.

It is also important to know what is considered as rural-type municipality and rural area in the research. A municipality of up to 2000 inhabitants is considered a rural-type municipality [5]. Rural area is considered to be an area in which more than $50 \%$ of the population lives in rural-type municipalities. The boundaries of this territory are set at the highest order of the municipality, i.e. administrative district of municipality with extended powers [6].

\section{$1 \quad$ Methodology}

The research is based on a questionnaire survey (in written and electronic form), where the target group are students of the last years of middle and upper degree study of the Liberec Region, meeting the definition of a young person according to the Ministry of Education [7], i.e. a person aged 15 to 29 years. Due to the lack of selection support, a judgmental technique was used in the sampling. Participation factors mentioned in the questionnaire were determined on the basis of literature search and realized focus groups.

The final survey was attended by $84.44 \%$ of secondary vocational schools, high schools and vocational colleges in the Liberec Region, as well as students of the Technical University of Liberec (TUL). The completed questionnaires represent approximately $42.90 \%$ of all potential respondents from secondary vocational schools, high schools and vocational colleges in the Liberec Region. About 1200 students were approached at TUL, with a return of about 13\%.

The data were evaluated in MS Excel and the statistical program Statgraphics Centurion. Descriptive statistics and dependency analysis of selected variables were used. The dependency analysis used the following tests: independence test of categorical variables, analysis of variance (or its non-parametric variant Kruskal-Wallis test), and marginally also regression analysis. In the case of data absence, the pairwise deletion was used: a method whereby only those rows that refer to at least one of the variables in the currently running calculations are discarded. Exploratory factor analysis was used to determine the participation factors of the young generation in family business. In this case, the listwise deletion was used.

A decision-making process has been defined for the participation of a young person in family business, which is divided into three phases. The first phase concerns the involvement of young people in family business during their studies. The second phase is the work of young people in family business after graduation. The third phase involves taking over the family business (succession). Based on these opportunities for young people to participate in family 
business, eight decision-making processes for participation have been identified and the participation matrix was created, see Table 1.

Tab. 1: Participation matrix

\begin{tabular}{|l|c|c|c|}
\hline $\begin{array}{l}\text { Participation } \\
\text { phase }\end{array}$ & $\begin{array}{c}\text { 1. Involvement during } \\
\text { studies }\end{array}$ & $\begin{array}{c}\text { 2. Work in FB after } \\
\text { studies }\end{array}$ & $\begin{array}{c}\text { 3. FB } \\
\text { succession }\end{array}$ \\
\hline \multirow{5}{*}{ Decision process } & YES & YES & YES \\
\cline { 2 - 4 } & YES & YES & NO \\
\cline { 2 - 4 } & YES & NO & YES \\
\cline { 2 - 4 } & YES & NO & NO \\
\cline { 2 - 4 } & NO & YES & YES \\
\cline { 2 - 4 } & NO & YES & NO \\
\cline { 2 - 4 } & NO & NO & YES \\
\cline { 2 - 4 } & NO & NO & NO \\
\hline
\end{tabular}

Source: Own

The first option, "YES-YES-YES", indicates that a young person is involved in family business during their studies and wants to be involved in this business after graduation and plans to take it over once. This decision-making process is called full participation.

The last option, "NO-NO-NO", points to a young person who did not engage in family business while studying, who does not want to work in the family business, and who does not even consider taking it over. Such a decision-making process was described as zero participation.

\section{$2 \quad$ Results and Discussion}

The topic of the doctoral thesis was to compile factors influencing participation of young people in family business leading to their willingness to take over the family business. Succession is a key issue for family business. In the Czech Republic, family business is also defined in terms of natural persons [8] but according to the results of group interviews it has emerged that students do not always realize that their relatives' business could be defined as family business. Furthermore, the context of the municipality in which the family business is run is omitted. Small crafts and services are typical in the countryside, for example in the hospitality industry [9].

The research has revealed that females tend to be more formally educated and respondents from rural villages have lower educational aspirations. It has been found out that female entrepreneurs are more likely to be self-employed (FB NP). In this type of family business there is often the same locality (municipality) of the business operation and the residence of the interviewee.

Within the Participation Matrix differences were found in the meaning of evaluated statements related to the participation or non-participation of students in family business. These differences were noted especially in the case of positive participation (involvement in family business), where some students participate in their family businesses because of tradition and a sense of family responsibility (e.g. full participation), for some of them it is often a sense of assurance which plays an important role.

In terms of the involvement of young people in family business, most of the interviewees did not participate in family business during their studies, nor did they want to work there or take it over. This is confirmed by the situation recorded for example by Zellweger [10] or in the Czech Republic by Antlová et al. [11]. However, young people who are already involved in 
family business during their studies want to work there after their graduation and then take it over. Therefore, if the owner of the company involves the young person in the business while studying, the young person will be more likely to take the family business over. Of course, opinions may change over the years. For example, Overbeke et al. [12] states that even those who had refused to work in their family businesses and to take over the family business during their youth, eventually became successors in family businesses. On the other hand, there may be situations that might affect the young person's willingness to take over the family business in their future. These reasons may be, for example, difficult relationship with new partners and family, conflicts that might occur within the family, etc.

As regards the characteristics affecting participation in family business, it has been found that men with lower ambitions to get formal education are generally more involved. This indicates craft orientation. Generally, higher involvement is more often observed in rural-type municipalities, especially in full participation. Furthermore, the influence of rural areas (administrative district of municipality with extended powers Jilemnice, Turnov and Železný Brod), in which succession is discussed more frequently than in urban areas, has also been shown. The discussion of succession in the family businesses is an underestimated issue. The indisputable influence, through all three phases of participation, have of course also family relationships, i.e. whether the student is in the direct family line of the family business incumbent. For some students, the reason for choosing their field of study has also been the existence of their family business. They plan to take it over in most cases.

As far as the involvement of women in family business during their studies is concerned, the role of a family business runner is important. In the case of male entrepreneurs, their female offspring are significantly less involved in family businesses than in the case of female entrepreneurs or cooperation of both genders. Higher educational ambitions often lead to the fact that students do not want to take over the family business. Such students would then be motivated to work in a Family Business Corporation rather than in a Family Business of Natural Persons. The type of family business has a particular impact on succession. More often, those with a family business corporation want to take over the family business, regardless of the type of municipality.

A problem with the gradual involvement of young people in entrepreneurship (and then with succession) has been identified especially among women, students with a higher ambition for education and Family Business of Natural Persons. See the basic scheme of participation in Figure 1 below. There are also scheme explanatory notes in Table 2.

Tab. 2: Scheme explanatory notes

\begin{tabular}{|l|l|}
\hline FB & Family business \\
\hline FB NP & Family Business of Natural Persons \\
\hline$\longrightarrow$ & Family Business Corporation \\
\hline$\longrightarrow$ & St influenced. \\
\hline$-\cdots-\cdot \rightarrow$ & It leads to a discussion of succession. \\
\hline$-\cdots-\cdot-$ & Insufficient succession communication. \\
\hline & Positive influence of rural municipality at the phase participation. \\
\hline
\end{tabular}

Source: Own 


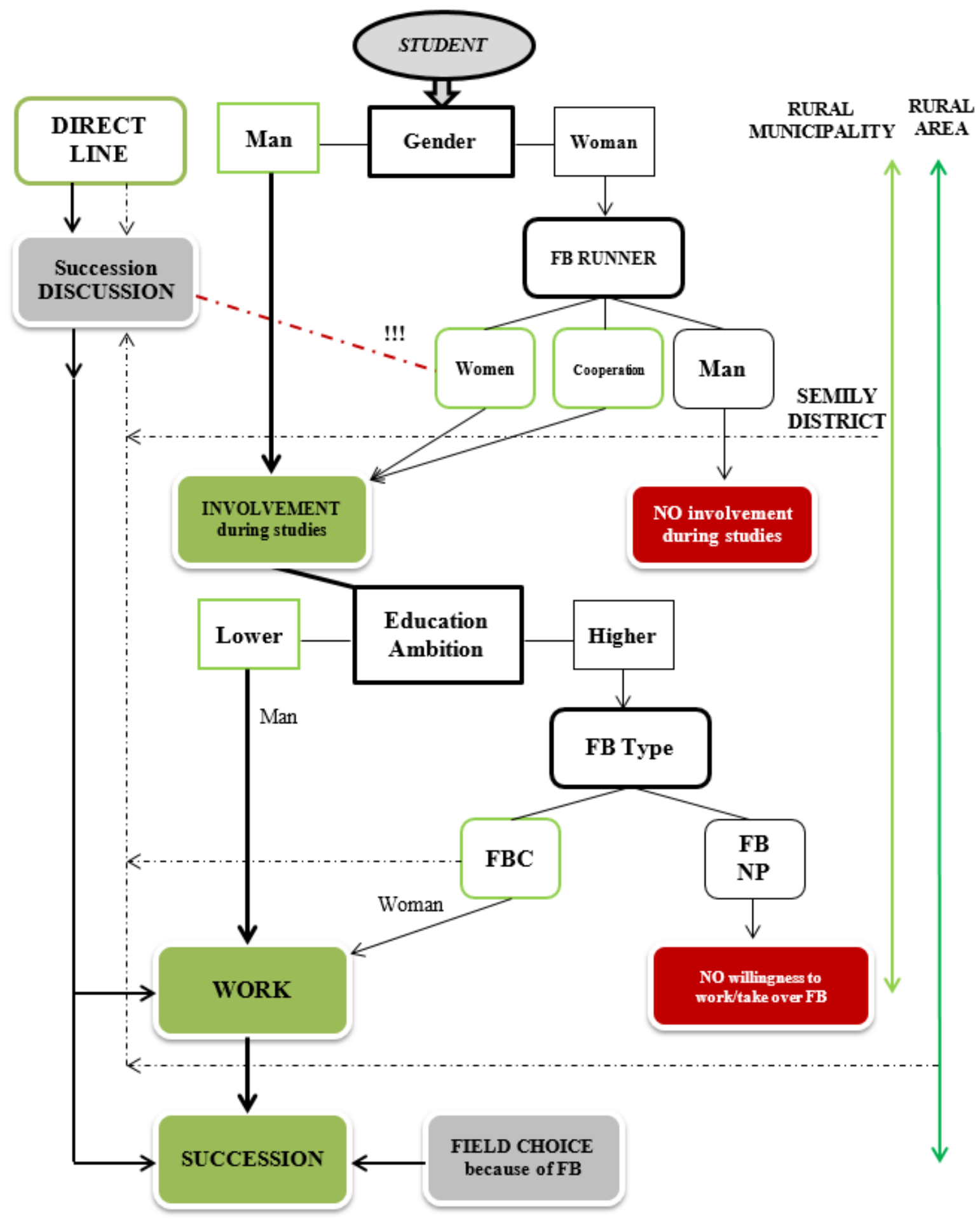

Source: Own

Fig. 1: Basic scheme of participation

Using explorative factor analysis of data, nine factors have been identified that influence the full participation of young people in family business. These factors are: assurance; pleasure from the field; emotional commitment; normative commitment; appeal to family; time flexibility; family relationships; management; property.

Furthermore, factors influencing zero participation of young people in family business were identified. The identified eleven factors include: non-entrepreneurship; family relationships; 
uselessness; time demands; location; relationship; development opportunities; lack of interest in the field; state of business; succession; ambitions.

Based on the identified correlations of factors and characteristics of both respondents and family businesses, it is possible to draw recommendations for the underlying scheme of participation.

For women who tend to have higher formal education and are likely to want to take over the business in the case of a Family Business Corporation, it is recommended to strengthen the emotional and normative commitment (generally family aspects) and sense of assurance for the Family Business of Natural Persons. Furthermore, it is important to enable the use of the studied field in the business, for example, by diversifying the product portfolio or by cooperation. Especially in rural municipalities it is important to enable the business development according to their ideas and to enable them to lead staff. In this type of municipalities, in case of Family Business of Natural Persons, it is particularly important to strengthen family relationships. In urban-type municipalities, it is recommended to strive to strengthen the emotional commitment factor also for students where a family business runner is a woman.

In young people with a higher ambition to achieve formal education, efforts should be made to promote development opportunities, which can begin, for example, by transforming the legal form of entrepreneurship and the current owner's efforts for business growth. However, this aspect is already rooted in the entrepreneurial mindset of the existing runner. Another possibility is to try to stimulate a young person to develop the business in order to capitalize on the experience of the current owner.

Entrepreneurship needs to be developed in urban areas, as fear of responsibility and administrative demand has been observed mainly in this type of area.

\section{Conclusion}

The research presented in the doctoral thesis was devoted to the complex decision-making process of young people pointing towards to succession in the context of the type of family business and the type of municipality. The factors that influence the phases of the decisionmaking process are listed above.

The research found that men are more involved in family business, in particular those with lower ambitions to achieve formal education. Furthermore, a greater influence of rural areas and rural municipalities was found compared to urban-type municipalities and areas. This fact is obvious for the countryside, because the crafts are rooted in tradition there.

Research has shown that women are more likely to engage in family business if the main incumbent is also female (or cooperation of both gender). However, women's desire to engage in business after graduation seems to be very weak. This is mainly because women have higher ambitions for formal education. Women are more likely to engage in business in case of Family Business Corporation. The research also revealed the absence of discussion on succession among female entrepreneurs, mainly in relation to female students. The absence of this discussion is related to women's negative approach to taking over family businesses.

Research in this area will continue, especially with regard to the field of family business studies and other fields of study chosen by young people, whose family member are engaged in family businesses.

Furthermore, the relation of young people (students) to the municipality, their will to stay in the municipality, and whether this approach differs for persons with a family business 
background, will also be examined. The basic scheme of participation should also be extended in the future.

The challenge for further research is to find out the role of main and secondary activity in family business. Does the proportion of non-family businesses with main or secondary business activity differ from the family business? Is participation of the young generation in family business different in the case of main and secondary activities? Are there different or identical factors of participation in these types of activities?

The research results are currently valid for the Liberec Region. However, each region has its own specifics. Another challenge for the future is the possibility of applying this research in other regions of the Czech Republic, then comparing the results and finding differences.

\section{Acknowledgements}

The doctoral thesis was written in the framework of SGS-EF-3300-21231 "Young Generation in Family Business in the Context of the Municipality“, Faculty of Economics, Technical University of Liberec.

\section{Literature}

[1] HORČIČKOVÁ, Z.: Participace mladé generace na rodinném podnikání. Liberec, 2019. Doctoral thesis (Ph.D.). Technical university of Liberec, Faculty of Economics. Supervisor prof. Ing. Ivan Jáč, CSc.

[2] ZELLWEGER, T.: Managing the Family Business: Theory and Practice. Edward Elgar Publishing Limited, UK, 2017. ISBN 978-1-78347-070-9.

[3] AMSP ČR: Definice rodinného podnikání. Press release dated 30. 1. 2018.

[4] RYDVALOVÁ, P. et al.: Typologie a hodnoceni vitality rodinného podnikání. Technická univerzita v Liberci, Liberec, 2017. ISBN: 978-80-7494-352-2.

[5] CZECH STATISTICAL OFFICE: Postavení venkova v Libereckém kraji. [online]. 2018. [accessed 2019-02-02]. Available from https://www.czso.cz/documents/10180/20565919/511361-09.pdf/fd927885-1345-41909ad7-105efb74eefc?version=1.0

[6] GAREP: Metodická podpora regionálního rozvoje. [online]. 2018. [accessed 2018-1226]. Available from WW: http://www.regionalnirozvoj.cz/index.php/regiony_red.html

[7] MINISTRY OF EDUCATION: Mládež v ČR. [online]. 2019. [accessed 2019-01-15]. Available from WWW: http://www.msmt.cz/mladez/mladez-v-cr

[8] AMSP ČR: Česká republika definovala, co je rodinné podnikání. [online]. 2019. [accessed 2019-07-23]. Available from https://www.businessinfo.cz/cs/clanky/ceska-republika-definovala-co-je-rodinnepodnikani-121083.html

[9] SVOBODOVÁ, H. et al.: Synergie ve venkovském prostoru. GaREP, spol. s r.o., Brno, 2011. ISBN: 978-80-904308-8-4.

[10] ZELLWEGER, T.; SIEGER, P.; HALTER, F.: Should I stay or should I go? Career choice intentions of students with family business background. Journal of Business Venturing. 2011. DOI: 10.1016/j.jbusvent.2010.04.001 
[11] ANTlOVÁ, K.; RYDVAlOVÁ, P.; LAMR, M.: Vztah studenti̊ k podnikání. Technická univerzita v Liberci, Liberec, 2017. ISBN: 978-80-7494-379-9.

[12] OVERBEKE, K. K.; BILIMORIA, D.; PERELLI, S.: The dearth of daughter successors in family businesses: Gendered norms, blindness to possibility, and invisibility. Journal of Family Business Strategy. 2013. DOI: 10.1016/j.jfbs.2013.07.002

Ing. Zuzana Horčičková, Ph.D. 


\section{PARTICIPACE MLADÉ GENERACE NA RODINNÉM PODNIKÁNÍ}

Výzkum byl zaměřen na studenty/studentky posledních ročníků učilišt', středních škol, vyšších odborných škol a dodatečně i veřejné vysoké školy v Libereckém kraji. Disertační práce se věnuje komplexnímu rozhodovacímu procesu mladých lidí vedoucímu $\mathrm{k}$ převzetí rodinného podnikání. Na základě výsledků analýz byl vytvořen základní schéma participace mladých lidí v rodinném podnikání $\mathrm{v}$ Libereckém kraji. Jsou zde zjištěny a shrnuty faktory, které jednotlivé fáze rozhodovacího procesu ovlivňují, přičemž je brán zřetel na typ obce, ve které je rodinné podnikání provozováno. Dále je zohledňován i typ rodinného podnikání, tj. zda se jedná o rodinnou obchodní korporaci či o rodinné podnikání fyzických osob.

\section{DIE MITWIRKUNG DER JUNGEN GENERATION BEIM FAMILIENUNTERNEHMEN}

Die Untersuchung galt den Schülerinnen und Schülern von Berufsschulen, Mittelschulen, Fachoberschulen und zusätzlich auch den Hochschulstudenten im Reichenberger Bezirk (Liberecký kraj) der letzten Jahrgänge. Die Dissertation widmet sich dem neuen komplexen Entscheidungsprozess der jungen Leute, welcher zur Übernahme eines Familienunternehmens führt. Auf Grundlage der Ergebnisse der Analyse wurde ein Grundmodell der Beteiligung junger Leute an Familienunternehmen im Reichenberger Bezirk erstellt. Es werden hierin die Faktoren fest- und zusammengestellt, welche die einzelnen Phasen des Entscheidungsprozesses beeinflussen, wobei der Typ der Gemeinde Berücksichtigung findet, in welcher das jeweilige Familienunternehmen betrieben wird. Weiter wird auch der Typ des Familienunternehmens berücksichtigt, d. h., ob es sich um eine Familiengeschäftskörperschaft oder um ein Familienunternehmen physischer Personen handelt.

\section{UDZIAŁ MŁODEGO POKOLENIA W BIZNESIE RODZINNYM}

Badania obejmowały studentów/studentki ostatnich roczników zasadniczych szkół zawodowych, szkół średnich, policealnych szkół zawodowych a także publicznych szkół wyższych w kraju libereckim. Praca dysertacyjna poświęcona jest kompleksowemu procesowi decyzyjnemu młodych osób prowadzącemu do przejęcia rodzinnego biznesu. $\mathrm{Na}$ podstawie wyników analiz opracowano podstawowy model udziału młodych osób w rodzinnym biznesie w kraju libereckim. Są tu wskazane i zebrane czynniki, które wpływają na poszczególne etapy procesu decyzyjnego, przy czym uwzględniono typ gminy, w której firma rodzinna jest prowadzona. Ponadto uwzględniono także typ rodzinnej działalności, to znaczy czy jest to rodzinna spółka prawa handlowego czy rodzinna firma prowadzona przez osoby fizyczne. 